\title{
Healthy Life Style Behaviors of University Students of School of Physical Education and Sports in Terms of Body Mass Index and Other Variables
}

\author{
Volkan Bozlar ${ }^{1, *}$, Cansel Arslanoğlu ${ }^{2}$ \\ ${ }^{1}$ Graduate School of Health Science, Kirikkale University, Turkey \\ ${ }^{2}$ Sarikamis School of Physical Education and Sport, Kafkas University, Turkey
}

Copyright $\mathrm{O} 2016$ by authors, all rights reserved. Authors agree that this article remains permanently open access under the terms of the Creative Commons Attribution License 4.0 International License

\begin{abstract}
The aim of this study is to determine Healthy Lifestyle Behaviors of students in the Schools of Physical Education and Sport (SPES) utilizing Body Mass Index (BMI) and other various variables. The study is composed of 1695 students studying in SPES, in 14 different universities across Turkey. It is made up of 1067 male and 624 female students. Data collected, is from both anonymous personal information and a Healthy Lifestyle Behaviors Scale - I survey. SPSS 21 was used and analysis obtained is 95\% reliant. Examining the difference in status between Healthy Lifestyle Behaviors scores and the BMI group were done according to the Kruskal-Wallis $\mathrm{H}$ test, examining the relationship between each BMI group with 6 subscales was done with the Spearman Correlation test. The highest average score of the subscale is Self-Fulfillment (37.25 \pm 6.02), while the lowest score of subscale was exercise (13.45 \pm 3.06 ). SPES students with low BMI's were found to have a higher score in the Self- Fulfillment subscale. Recreation Department students scored higher in 4 of the 6 subscales, whereas the 4th grade students scored higher in 5 of the 6 subscales. It has been observed that as the family income and education level increases, there is an increase in the awareness of the Healthy Lifestyle Behaviors applied. The findings of the literature have revealed that there is a serious lack of exercise and proper nutrition, and the results for the SPES students observed in this regard were no different. This research supports the need for well-rounded encouragement and support as it pertains to healthy living. Also the students with low BMI's showed higher scores in the subscale of SelfFulfillment. The students majoring in Recreation received higher scores on several subscales.
\end{abstract}

Keywords Physical Education, Sport, Healthy Life Style, BMI

\section{Introduction}

Health has been one of the concepts that have been heavily focused on since the beginning of humanity. Health can be considered as a continuum which covers different levels between healthy status at an optimum level and death [1]. According to the World Health Organization, health is more than the status of not having a disease or disability but a status of being well in terms of mental, physical and social aspects. Being healthy, according to the same organization, is defined as "being aware of breathing, being able to meet the needs, being able to change the environment or handle the environment" [2].

There are several factors involved in health and illness. Health is influenced by poor eating habits, not exercising enough, excessive stress, personal traits, behaviors and attitudes $[3,4]$. Unhealthy habits seen in adulthood are said to be strongly associated with an unhealthy life style in adolescence $[5,6]$. However, the fact that the foundation of diseases seen in society is based on the childhood and teenage periods is ignored most of the time [7].

When the development process of medicine and healthcare services are considered, we see that trying to heal the ones who are ill comes first and then ways to prevent diseases are addressed later [8]. Healthy life style behaviors aim not only to prevent a disease or illness but also to bring a person's general health to a better level. Immobility and a lack of healthy habits are the main reasons health problems occur today. It is stated that healthy life style behaviors can reduce diseases and death on one hand and research conducted on large portions of society show that an immobile life style causes several chronic diseases on the other [9.10.11.12]. The healthy life style scale developed within this context includes physical activity, self-fulfillment, health responsibility, nutrition, support among people and stress management components [13]. Health responsibility is a person being actively responsible for his personal health. Physical activity is defined as doing exercises at every level regularly. Nutrition is defined as an individual's choice and management of his meals and the value of his food. Moral development focuses on the development of inner resources. Interpersonal relationships are the relationships with others 
and require use of communication. Stress management is to determine and activate an individual's physiological and psychological resources to reduce and control intensity [14].

Considering the fact that the foundation of many diseases and illnesses is based on childhood and teenage period and how important this issue is, this research is anticipated to raise awareness in students of School of Physical Education and Sports (SPES), improving and contributing to the development of current behaviors related to health. When research on healthy lifestyle behaviors in Turkey is examined, it is seen that very few studies are conducted generally in university students (with the exception of nursing students). This research aims to examine healthy life style behaviors of SPES students in terms of Body-Mass Index (BMI) and other health variables.

\section{Material and Method}

This study is a descriptive study using valid survey. The sample of this study consists of SPES students $(n=1870)$ from 14 different universities in Turkey chosen randomly. Contributions from universities to this study are listed in a descending order; Adnan Menderes University $(11,2)$, Kafkas University $(10,8)$, Ordu University $(10,3)$, Erciyes University $(9,9)$, Dumlupinar University $(9,4)$, Karadeniz Technical University $(8,0)$, Yuzuncu Yil University $(7,1)$, Gazi University $(7,0)$, Cukurova University $(5,3)$, Karabuk University (4,7), Batman University $(4,7)$, Mehmet Akif Ersoy University (4,0), Adiyaman University $(3,8)$, Marmara University $(3,8)$.

1695 surveys out of 1870 that are sent out to be answered are considered acceptable and organized in order to be used in the analysis. 1067 of the surveys taken into analysis were answered by male students while 624 were answered by female students. Some survey takers did not answer some of the questions in the personal information section but completed the scale.

\section{Data Gathering Tools}

Personal Information Form: 15 questions were asked in the personal information form related to determination of students' socio-demographical characteristics and BMI.

Healthy Life Style Behaviors Scale: Walker et al.[14], developed the healthy lifestyle behaviors scale to test the Improving Health Model introduced by Pender in 1987 [15]. This scale measures behaviors that improve an individual's health related to healthy lifestyle. The validity and reliability of this scale was conducted by Esin M. N in Turkey [16] and this scale was used in many studies. There are a total of 48 items and 6 sub-scales in the scale. These sub question groups are related to self-fulfillment, health responsibility, exercise, nutrition, interpersonal support and stress management.

\section{Data Analysis}

Data gathered by surveys were entered into the SPSS 21.0 packet program and statistical analysis was carried out with a $95 \%$ reliability range. Personal information related to frequency and percentage values related to data gathered from the personal information form are presented within the scope of the study. Normality test was conducted to determine the conformity to normal distribution and the analysis showed that the scores were not in conformity with normal distribution. Therefore, kruskal wallish and Man Whitney $U$ tests were used. The level of significance was determined according to $\mathrm{p}<0.05$.

When calculating the BMI, weight (kg)/height (m) formula was used. According to BMI values, people under 18,5 were grouped as underweight, ones that are between 18,5 and 24,99 are normal weight, between 25,00 and 29,99 are overweight and over 30,0 are as obese.

\section{Findings}

Table 1. Socio-Demographical Information

\begin{tabular}{|c|c|c|c|}
\hline & & $\mathrm{N}$ & $\%$ \\
\hline Age & $16-17$ & 7 & 0,4 \\
\hline & $18-20$ & 512 & 30,3 \\
\hline & $21-22$ & 651 & 38,5 \\
\hline & $23-24$ & 355 & 21,0 \\
\hline BMI & 25 and older & 167 & 9,9 \\
\hline & Underweight & 134 & 7,9 \\
\hline & Normal & 1372 & 80,9 \\
\hline & Overweight & 176 & 10,4 \\
\hline Gender & Obese & 13 & 0,8 \\
\hline & Female & 624 & 36,9 \\
\hline \multirow{2}{*}{\begin{tabular}{c} 
Department \\
\hline
\end{tabular}} & Male & 1067 & 63,1 \\
\hline & Teacher & 585 & 34,6 \\
\hline & Coprts Management & 596 & 35,2 \\
\hline & Recreation & 144 & 8,5 \\
\hline $\begin{array}{c}\text { Are you a } \\
\text { professional } \\
\text { athlete? }\end{array}$ & Yes & 834 & 49,2 \\
\cline { 2 - 4 } & No & 860 & 50,8 \\
\hline
\end{tabular}

Table 2. Normality Test of Dimensions of Healthy Life Style Behavior Scale

\begin{tabular}{|c|c|c|c|c|c|c|}
\hline & \multicolumn{3}{|c|}{ Kolmogorov-Smirnov $^{\mathrm{a}}$} & \multicolumn{3}{c|}{ Shapiro-Wilk } \\
\cline { 2 - 7 } & Statistic & $\mathrm{df}$ & Sig. & Statistic & $\mathrm{df}$ & Sig. \\
\hline Exercise &, 087 & 1695 &, 000 &, 982 & 1695 &, 000 \\
\hline Nutrition &, 067 & 1695 &, 000 &, 989 & 1695 &, 000 \\
\hline $\begin{array}{c}\text { Health } \\
\text { Responsibility }\end{array}$ &, 046 & 1695 &, 000 &, 993 & 1695 &, 000 \\
\hline $\begin{array}{c}\text { Interpersonal } \\
\text { Support }\end{array}$ &, 066 & 1695 &, 000 &, 960 & 1695 &, 000 \\
\hline Self-Fulfillment &, 040 & 1695 &, 000 &, 994 & 1695 &, 000 \\
\hline $\begin{array}{c}\text { Stress } \\
\text { Management }\end{array}$ &, 070 & 1695 &, 000 &, 966 & 1695 &, 000 \\
\hline
\end{tabular}

Shapiro-Wilk Test that is done for the scales of exercise, nutrition, health responsibility, interpersonal support, 
self-fulfillment, stress management score average, showed that the data do not show a normal distribution. Therefore, non-parametric techniques were used in intergroup comparisons.

Table 3. Dimensions of Healthy Life Style Behavior Scale

\begin{tabular}{|c|c|c|c|c|c|}
\hline & $\mathrm{N}$ & Minimum & Maximum & Average & ss \\
\hline Exercise & 1695 & 5,00 & 33,00 & 13,45 & 3,06 \\
\hline Nutrition & 1695 & 6,00 & 24,00 & 15,51 & 3,40 \\
\hline $\begin{array}{c}\text { Health } \\
\text { Responsibility }\end{array}$ & 1695 & 10,00 & 38,00 & 23,57 & 5,56 \\
\hline $\begin{array}{c}\text { Interpersonal } \\
\text { Support }\end{array}$ & 1695 & 8,00 & 54,00 & 20,25 & 3,82 \\
\hline Self-Fulfillment & 1695 & 15,00 & 52,00 & 37,25 & 6,02 \\
\hline Stress Management & 1695 & 8,00 & 56,00 & 18,70 & 3,67 \\
\hline
\end{tabular}

The survey takers' average score of exercise is $13,45 \pm 3,06$; average score of nutrition is $15,51 \pm 3,40$; average score of health responsibility is $23,57 \pm 5,56$; average score of interpersonal support is $20,25 \pm 3,82$; average score of self-fulfillment $37,25 \pm 6,02$ and average score of stress management is $18,70 \pm 3,67$.

Table 4. Comparison of Groups with Different Body-Mass Index

\begin{tabular}{|c|c|c|c|c|c|}
\hline \multicolumn{2}{|l|}{ BMI } & $\mathrm{N}$ & Mean Rank & $\mathrm{X} 2$ & $\mathrm{P}$ \\
\hline \multirow{4}{*}{ Exercise } & Underweight & 134 & 811,70 & \multirow{4}{*}{1,179} & \multirow{4}{*}{,758 } \\
\hline & Normal & 1372 & 848,37 & & \\
\hline & Overweight & 176 & 870,08 & & \\
\hline & Obese & 13 & 884,31 & & \\
\hline \multirow{4}{*}{ Nutrition } & Underweight & 134 & 848,12 & \multirow{4}{*}{6,671} & \multirow{4}{*}{, 083} \\
\hline & Normal & 1372 & 836,77 & & \\
\hline & Overweight & 176 & 937,33 & & \\
\hline & Obese & 13 & 822,77 & & \\
\hline \multirow{4}{*}{$\begin{array}{c}\text { Health } \\
\text { Responsibility }\end{array}$} & Underweight & 134 & 929,07 & \multirow{4}{*}{6,242} & \multirow{4}{*}{, 100} \\
\hline & Normal & 1372 & 836,42 & & \\
\hline & Overweight & 176 & 863,86 & & \\
\hline & Obese & 13 & 1019,46 & & \\
\hline \multirow{4}{*}{$\begin{array}{c}\text { Interpersonal } \\
\text { Support }\end{array}$} & Underweight & 134 & 880,54 & \multirow{4}{*}{2,163} & \multirow{4}{*}{,539 } \\
\hline & Normal & 1372 & 839,59 & & \\
\hline & Overweight & 176 & 887,00 & & \\
\hline & Obese & 13 & 872,58 & & \\
\hline \multirow{4}{*}{ Self-Fufilment } & Underweight & 134 & 941,87 & \multirow{4}{*}{9,630} & \multirow{4}{*}{, 022} \\
\hline & Normal & 1372 & 831,10 & & \\
\hline & Overweight & 176 & 911,35 & & \\
\hline & Obese & 13 & 806,81 & & \\
\hline \multirow{4}{*}{ Stress Management } & Underweight & 134 & 906,98 & \multirow{4}{*}{5,171} & \multirow{4}{*}{, 160} \\
\hline & Normal & 1372 & 835,25 & & \\
\hline & Overweight & 176 & 894,15 & & \\
\hline & Obese & 13 & 960,81 & & \\
\hline
\end{tabular}

$\mathrm{p}<0,05$
Table 5. Comparison of Scale Scores in Terms of Age Variable

\begin{tabular}{|c|c|c|c|c|c|}
\hline & Age & $\mathrm{n}$ & Mean Rank & $\mathrm{X} 2$ & $\mathrm{P}$ \\
\hline \multirow{5}{*}{ Exercise } & $16-17$ & 7 & 1196,86 & \multirow{5}{*}{10,121} & \multirow{5}{*}{, 038} \\
\hline & $18-20$ & 512 & 881,82 & & \\
\hline & $21-22$ & 651 & 812,04 & & \\
\hline & $23-24$ & 355 & 839,97 & & \\
\hline & $25 \geq$ & 167 & 871,73 & & \\
\hline \multirow{5}{*}{ Nutrition } & $16-17$ & 7 & 720,29 & \multirow{5}{*}{14,446} & \multirow{5}{*}{,006 } \\
\hline & $18-20$ & 512 & 808,60 & & \\
\hline & $21-22$ & 651 & 828,16 & & \\
\hline & $23-24$ & 355 & 890,07 & & \\
\hline & $25 \geq$ & 167 & 946,87 & & \\
\hline \multirow{5}{*}{$\begin{array}{c}\text { Health } \\
\text { Responsibility }\end{array}$} & $16-17$ & 7 & 751,71 & \multirow{5}{*}{12,862} & \multirow{5}{*}{, 012} \\
\hline & $18-20$ & 512 & 795,57 & & \\
\hline & $21-22$ & 651 & 842,77 & & \\
\hline & $23-24$ & 355 & 897,09 & & \\
\hline & $25 \geq$ & 167 & 913,63 & & \\
\hline \multirow{5}{*}{$\begin{array}{c}\text { Interpersonal } \\
\text { Support }\end{array}$} & $16-17$ & 7 & 862,93 & \multirow{5}{*}{7,400} & \multirow{5}{*}{, 116} \\
\hline & $18-20$ & 512 & 847,70 & & \\
\hline & $21-22$ & 651 & 819,08 & & \\
\hline & $23-24$ & 355 & 854,16 & & \\
\hline & $25 \geq$ & 167 & 932,72 & & \\
\hline \multirow{5}{*}{ Self-Fulfillment } & $16-17$ & 7 & 998,21 & \multirow{5}{*}{8,929} & \multirow{5}{*}{, 063} \\
\hline & $18-20$ & 512 & 842,66 & & \\
\hline & $21-22$ & 651 & 824,15 & & \\
\hline & $23-24$ & 355 & 843,56 & & \\
\hline & $25 \geq$ & 167 & 945,27 & & \\
\hline \multirow{5}{*}{$\begin{array}{c}\text { Stress } \\
\text { Management }\end{array}$} & $16-17$ & 7 & 724,93 & \multirow{5}{*}{9,350} & \multirow{5}{*}{, 053} \\
\hline & $18-20$ & 512 & 823,11 & & \\
\hline & $21-22$ & 651 & 825,75 & & \\
\hline & $23-24$ & 355 & 882,81 & & \\
\hline & $25 \geq$ & 167 & 927,04 & & \\
\hline
\end{tabular}

$\mathrm{p}<0,05$

According to Kruskal Wallis test performed for different age groups, statistically significant difference was found in the exercise, nutrition and health responsibility scale $(\mathrm{p}<0,05)$.

Table 6. Comparison of Scale Scores in Terms of Gender Variable

\begin{tabular}{|c|c|c|c|c|c|}
\hline \multicolumn{2}{|c|}{ Gender } & $\mathrm{n}$ & Mean Rank & U & $\mathrm{P}$ \\
\hline \multirow{2}{*}{ Exercise } & female & 624 & 779,34 & \multirow{2}{*}{291311,000} & \multirow{2}{*}{, 000} \\
\hline & male & 1067 & 884,98 & & \\
\hline \multirow{2}{*}{ Nutrition } & female & 624 & 806,93 & \multirow{2}{*}{308526,500} & \multirow{2}{*}{, 012} \\
\hline & male & 1067 & 868,85 & & \\
\hline \multirow{2}{*}{$\begin{array}{c}\text { Health } \\
\text { Responsibility }\end{array}$} & female & 624 & 859,71 & \multirow{2}{*}{324350,500} & \multirow{2}{*}{, 377} \\
\hline & male & 1067 & 837,98 & & \\
\hline \multirow{2}{*}{$\begin{array}{c}\text { Interpersonal } \\
\text { Support }\end{array}$} & female & 624 & 794,12 & \multirow{2}{*}{300528,500} & \multirow{2}{*}{, 001} \\
\hline & male & 1067 & 876,34 & & \\
\hline \multirow{2}{*}{ Self-Fulfillment } & female & 624 & 849,47 & \multirow{2}{*}{330738,500} & \multirow{2}{*}{, 823} \\
\hline & male & 1067 & 843,97 & & \\
\hline \multirow{2}{*}{$\begin{array}{c}\text { Stress } \\
\text { Management }\end{array}$} & female & 624 & 825,10 & \multirow{2}{*}{319860,000} & \multirow{2}{*}{, 177} \\
\hline & male & 1067 & 858,22 & & \\
\hline
\end{tabular}


According to the comparison in terms of gender with Mann Whitney test, statistically significant difference was found in exercise, nutrition and interpersonal support scale $(\mathrm{p}<0,05)$.

Table 7. Comparison of Scale Scores in Terms of Department Variable

\begin{tabular}{|c|c|c|c|c|c|}
\hline \multicolumn{2}{|c|}{ Department } & $\mathrm{n}$ & $\begin{array}{l}\text { Mean } \\
\text { Rank }\end{array}$ & $\mathrm{X} 2$ & $\mathrm{P}$ \\
\hline \multirow{4}{*}{ Exercise } & $\begin{array}{l}\text { Physical Education } \\
\text { and Sports Teaching }\end{array}$ & 585 & 837,31 & \multirow{4}{*}{4,729} & \multirow{4}{*}{, 193 } \\
\hline & Sports Management & 596 & 826,32 & & \\
\hline & Coaching Education & 367 & 893,93 & & \\
\hline & Recreation & 144 & 846,49 & & \\
\hline \multirow{4}{*}{ Nutrition } & $\begin{array}{l}\text { Physical Education } \\
\text { and Sports Teaching }\end{array}$ & 585 & 831,35 & \multirow{4}{*}{8,236} & \multirow{4}{*}{041} \\
\hline & Sports Management & 596 & 836,21 & & \\
\hline & Coaching Education & 367 & 844,08 & & \\
\hline & Recreation & 144 & 956,79 & & \\
\hline \multirow{4}{*}{$\begin{array}{c}\text { Health } \\
\text { Responsibility }\end{array}$} & $\begin{array}{l}\text { Physical Education } \\
\text { and Sports Teaching }\end{array}$ & 585 & 880,81 & \multirow{4}{*}{8,990} & \multirow{4}{*}{, 029} \\
\hline & Sports Management & 596 & 815,74 & & \\
\hline & Coaching Education & 367 & 817,09 & & \\
\hline & Recreation & 144 & 909,40 & & \\
\hline \multirow{4}{*}{$\begin{array}{l}\text { Interpersonal } \\
\text { Support }\end{array}$} & $\begin{array}{c}\text { Physical Education } \\
\text { and Sports Teaching }\end{array}$ & 585 & 824,92 & \multirow{4}{*}{9,717} & \multirow{4}{*}{, 021} \\
\hline & Sports Management & 596 & 848,51 & & \\
\hline & Coaching Education & 367 & 831,95 & & \\
\hline & Recreation & 144 & 962,92 & & \\
\hline \multirow{4}{*}{ Self-Fulfillment } & $\begin{array}{l}\text { Physical Education } \\
\text { and Sports Teaching }\end{array}$ & 585 & 819,62 & \multirow{4}{*}{6,661} & \multirow{4}{*}{, 084} \\
\hline & Sports Management & 596 & 857,72 & & \\
\hline & Coaching Education & 367 & 837,49 & & \\
\hline & Recreation & 144 & 932,24 & & \\
\hline \multirow{4}{*}{$\begin{array}{c}\text { Stress } \\
\text { Management }\end{array}$} & $\begin{array}{l}\text { Physical Education } \\
\text { and Sports Teaching }\end{array}$ & 585 & 852,74 & \multirow{4}{*}{9,760} & \multirow{4}{*}{021} \\
\hline & Sports Management & 596 & 831,71 & & \\
\hline & Coaching Education & 367 & 816,39 & & \\
\hline & Recreation & 144 & 959,12 & & \\
\hline
\end{tabular}

Statistically significant difference was found in sub-scales of nutrition, health responsibility, interpersonal support and stress management $(\mathrm{p}<0,05)$.

Table 8. Comparison of Groups of Professional and Amateur Athletes

\begin{tabular}{|c|c|c|c|c|c|}
\hline \multicolumn{2}{|c|}{$\begin{array}{c}\text { Are you a professional } \\
\text { athlete? }\end{array}$} & $\mathrm{n}$ & $\begin{array}{l}\text { Mean } \\
\text { Rank }\end{array}$ & $\mathrm{U}$ & $\mathrm{P}$ \\
\hline \multirow{2}{*}{ Exercise } & Yes & 834 & 978,34 & \multirow{2}{*}{249500,00} & \multirow{2}{*}{, 000} \\
\hline & No & 860 & 720,62 & & \\
\hline \multirow{2}{*}{ Nutrition } & Yes & 834 & 894,11 & \multirow{2}{*}{319751,00} & \multirow{2}{*}{, 000} \\
\hline & No & 860 & 802,30 & & \\
\hline \multirow{2}{*}{$\begin{array}{c}\text { Health } \\
\text { Responsibility }\end{array}$} & Yes & 834 & 894,36 & \multirow{2}{*}{319537,00} & \multirow{2}{*}{000} \\
\hline & No & 860 & 802,05 & & \\
\hline \multirow{2}{*}{$\begin{array}{l}\text { Interpersonal } \\
\text { Support }\end{array}$} & Yes & 834 & 870,90 & \multirow{2}{*}{339101,00} & \multirow{2}{*}{, 052} \\
\hline & No & 860 & 824,80 & & \\
\hline \multirow{2}{*}{ Self-Fulfillment } & Yes & 834 & 894,92 & \multirow{2}{*}{319074,00} & \multirow{2}{*}{, 000} \\
\hline & No & 860 & 801,52 & & \\
\hline \multirow{2}{*}{ Stres Management } & Yes & 834 & 881,06 & \multirow{2}{*}{330635,00} & \multirow{2}{*}{,005 } \\
\hline & No & 860 & 814,96 & & \\
\hline
\end{tabular}

According to the Mann Whitney $U$ test performed in groups of professional and amateur athletes, significant difference was found in between the groups in terms of exercise, nutrition, health responsibility, self-fulfillment and stress management sub-dimensions $(p<0,05)$. The scores of people who are professionals, are higher than the other group in all sub-dimensions. There is no statistically significant difference in the interpersonal support scale $(\mathrm{p}>0.05)$.

\section{Discussion}

This section presents the comparison and comments of our findings contributing to the related literature findings.

In terms of average Healthy Life Style Behavior Scale subscale scores

When the situation is evaluated, it is seen that the highest score average among the answers provided by students is self-fulfillment $(37,25 \pm 6,02)$. This is followed by health responsibility $(23,57 \pm 5,56)$, interpersonal support $(20,25 \pm 3,82)$, stress management $(18,70 \pm 3,67)$, nutrition $(15,51 \pm 3,40)$ and exercise $(13,45 \pm 3,06)$ consecutively (Table 3).

Similarly to our study, in most studies it is seen that self-fulfillment sub-scale takes the first place and exercise takes the last $[17,18,19,20,21,22]$.

In a study performed in Malatya, the healthy lifestyle behavior scale score averages of physical education teachers are found higher than the results of studies performed in different countries and regions using healthy lifestyle behavior scale [23]. Nevertheless, when studies in this field are considered generally, the fact that the lowest scores are in nutrition and physical activity sub-scales and having the same result in our study was unexpected from SPES students. In a study conducted in medical students by Nacar et al. in 2014, a similar paradox was identified [24]. Although it was assumed that first year medical students do not have much information on healthy living, they scored higher in several sub-scales while senior year medical students who are to be doctors soon scored lower.

In a study conducted among university students in Mexico, the order was as follows: self-fulfillment, interpersonal relationships, nutrition, stress management, health responsibility and physical activity [25]. In a study conducted in nursing students in the United States of America, the highest scores were in interpersonal relations and self-fulfillment sub-dimensions while the lowest score was in health responsibility [26]. The reason that self-fulfillment sub-scale gets the first place is thought to be influenced by societal and personal beliefs while the reason for the exercise sub-scale taking the last place is thought to be a lack of full understanding of sports culture in society, the costs of gyms, living conditions in the society in general and lack of time as a result of this, not having alternative sport fields at the desired level. 


\section{When the results are considered in terms of BMI}

No statistically significant difference was found in terms of exercise, nutrition, health responsibility, interpersonal support and stress management scales while those with underweight BMIs have the highest mean rank in self-fulfillment scale (Table 4).

When we compared our findings with the literature, we found that underweight and normal BMI groups have generally healthier profiles. A study by Firinci showed that according to BMI, "underweight" students are more emotional in "interpersonal relationships" compared to other students [27]. Additionally, there are studies where no significant difference was determined with different BMI groups and healthy lifestyle behavior total and sub-scale score averages [28]. Also, a study conducted with American adults showed that stressful life, changes related to work and death of a family member or a friend increases BMIs of women especially [29].

These data show the importance of having BMI measures in the "normal" rating and the link to positive health behaviors. In our comprehensive study and with broad participation across several schools and departments, the interesting point was to find a statistically significant difference only in self-fulfillment scale out of six sub-scales as it pertains to BMI.

\section{In terms of Different Age Groups}

Interpersonal support, self-fulfillment, stress management were not statistically significantly different while average mean rank of exercise scale of students at the age of 16 and 17 and the sub-scales of nutrition and health responsibility of students that are 25 and older have the highest average mean rank (Table 5).

Literature search showed parallelism with our findings. For instance, a study showed that the scores of sub-scales of health responsibility and nutrition are higher in older ages [30] while another study performed with university students from different majors showed that scores of nutrition and health responsibility sub-scales are higher among older students compared to young students [31]. In another study performed with Firat University Health College this difference was prominent in health responsibility and interpersonal support scores in older ages [32]. A study done in Nursing College in Istanbul, the average scores of students in 22-25 age groups in self-fulfillment, health responsibility and interpersonal support were found to be higher compared to 17-21 age group [33]. Aside from these, there is a study showing that especially health responsibility increases as the age increases [19]. In a study conducted in Mexico, it was found that students in the age group 17-24 have higher score average in physical activity, stress management and interpersonal support sub-scales parallel to our findings compared to students at the age of 25 and older [25]. In another study done in America, it was found that student at an older age have higher scores in scale total score and health responsibility sub-scale [26]. Different from our findings, there is a study where there is no statistically significant difference in healthy lifestyle behavior scale total [30].

When we evaluate the results, it is seen that individuals who are younger put more importance on physical activity and exercise while individuals who are 25 and older are more responsible with health and their nutrition. In similar studies, it is understood that health responsibility awareness become predominant as the age increases, similar to our findings, and some differences can show changes according to the country, region or areas where the research takes place.

\section{In terms of Gender Variable}

Statistically no significant difference was found in between female and male student groups in terms of health responsibility, self-fulfillment and stress management sub-scales while mean rank scores of males in nutrition and interpersonal support sub-scales are higher than female scores (Table 6).

Our results show parallelism with some research results. In a study conducted in high school students in Adana, the scores of males in nutrition and exercise sub-scales were found higher than females [34]. In a study conducted with nursing college students, males received higher scores in exercise sub-scale [33]. In studies performed with university students in Hong Kong and Mexico and studies performed in America with 11-15 year old teens, it was found that males place more importance on exercise than females $[25,35,36]$. In a study performed with academic personnel in university, the average scores of male academicians in exercise sub-scale were found higher than female academicians [37].

Different than our findings, in a study conducted with 208 physical education teachers, female teachers were found to have higher score average than male teachers in nutrition while no significant difference was found between groups in terms of exercise and interpersonal support sub-scales [23]. Studies performed in African Americans [38] and students in Uludag University Health College [39] showed that female students have higher scores in nutrition and interpersonal support sub-scales and statistically significant difference in between the groups. In a university in Japan, female students showed better results than males in interpersonal support and nutrition sub-scales while males were more prominently represented than females in exercise sub-scale [40].

\section{In terms of Department Variable}

When the subject of study is evaluated, students in recreation departments have higher mean rank average in terms of nutrition, health responsibility, interpersonal support and stress management compared to students in other departments (Table 7).

There is research in literature that compares different departments. For instance, in a study done in students from nursing, medical school, computer engineering and statistics departments, a relationship was found between departments and only health responsibility sub-scale. In another study 
performed in students of medicine, dentistry, nursing and midwifery, score average of medical students in all sub-scales except physical activity, and in scale total was found significantly lower compared to other departments. Also, another study performed in first year and senior year students from different medical schools in Turkey showed that first year students score significantly higher in several sub-scales while senior year students have lower scores [24]. Another study showed that students in life sciences have higher score average in health responsibility sub-scale compared to students in social sciences while students in healthcare have higher score averages compared to students in social sciences and vocational schools [31].

When our findings are considered, mean rank scores of recreation students in four sub-scales (Nutrition, Health Responsibility, Interpersonal Support and Stress Management) are found to be higher than other departments. This finding is important in terms of being a reference for further studies and the impact of school programs on student health.

In terms of Groups of Professional and Amateur Athletes

When professional athletes are compared with amateur athletes, their mean rank scores are found to be higher in terms of exercise, nutrition, health responsibility, self-fulfillment and stress management sub-scales (Table 8). Additionally, in a study conducted by Bercin (2010), students who are engaged in social activities were found to have higher scores in total score in healthy lifestyle behavior and in all sub-scales except nutrition compared to students who are not engaged in social activities [41]. Another study showed higher scores for students who engage in sports activities than who do not, in terms of all sub-scales except nutrition, and in total score averages in healthy lifestyle behavior. In a study done in middle school students in Isparta [42], students who engage in sports activities regularly are better than students who do not, in terms of personal traits such as being outgoing and open. Also, these students were found to be prominently represented in terms of academic success. It is clear that individuals who engage in sports activities regularly and who are professional athletes get higher scores in almost all healthy lifestyle behavior sub-scales or they have more positive attitudes and habits related to health. Results of some studies have shown this athlete population does not make healthy eating part of their healthy lifestyle [43].

\section{Conclusions}

This study examined healthy life style behaviors of students of SPES evaluating BMI and other health variables, it was found that the highest score average was achieved in Self-Fulfillment sub-scale $(37,25 \pm 6,02)$ while the lowest score average was in exercise $(13,45 \pm 3,06)$. SPES students whose BMIs are underweight were found to have higher scores in Self-Fulfillment sub-scale. So there is a negative correlation between BMI and Self-Fulfillment. Students in recreation were found to get higher scores in 4 sub-scales out of 6 while fourth year students have higher scores in 5 sub-scales out of 6 . We can say that, when the grade level of students increase, they show more healthy life style behaviours.

\section{Acknowledgements}

It has been accepted as a master thesis in Kafkas University Institute of Natural and Applied Science.

\section{REFERENCESS}

[1] Phalank, C., 1991, Determinant of Health Promotive Behavior; a Preview of Current Research, Nursing Clinic North America, 26(4), 815-832.

[2] World Health Organization (WHO) Health Promotion (1986): A Discussion Document on The Concept and Principles Public Health Rev., 14, 245-254.

[3] Ebersole, P., Hess, P., Theris A. Touhy, Kathleen F Jett 1990, Toward Healthy Aging, Human Needs and Nursing Response, ISBN-13: 978-0323073165, Third ed., The C.V. Mosby Company.

[4] Lewis S. M., Collier I.C., 1987, Medical Surgical Nursing Assesment and Management of Clinical Problems Sec. ed. Mc Graw-Hill Book Company, USA.

[5] Krueger, P.M. and Chang, V.W., 2008, Being Poor and Coping with Stress: Health Behaviors and the Risk of Death, American Journal of Public Health, 98(5), 889-896.

[6] Lowry, R. Galuska DA, Fulton JE, Wechsler H, Kann L, Collins JL. 2000, Physical Activity, Food Choice and Weight Management Goals and Practices Among U.S. College Students. American Journal of Preventive Medicine, 18(1), 18-27.

[7] Rodriguez, VG. Libersa C. Maria IM. Laurent B. Catalina I. Luis AMA. Jean D. Frédéric G. 2007, Healthy Lifestyle by Nutrition in Adolesce (HELENA). A New EU Funded Project .Therapie, 62(3), 259-270.

[8] Hardrick, G. and Lindsey, E., 1996, Health Promotion Nursing Practice: The Demise of Nursing Process, Journal of Adv. Nursing, 23, 106-112.

[9] Edelman, C., Mandle, C.L., 1986, Health Promotion Throughout the Lifespan, The C.V.Mosby Company, St Luis, Toronto, Princeton.

[10] Pender, N.J., 1987, Health Promotion in Nursing Practice (Second ed.), Norwalk CT, California

[11] Redland, A.R. and Stuifbergen, A.K., 1993, Stategies For Maintenance of Health Promoting Behaviours The Nursing Clinics of North America, 28(2), 427-442.

[12] Costanzo, C. Walker SN, Yates BC, McCabe B, Berg K. 2006, Physical Activity Counselling for Older Women West Journal Nursing Res., 28(7), 786-801. 
[13] Maurer, F. and Smith, C., 2000, Community Health Nursing Theory and Practice, WB Saunders Company, 404-424.

[14] Walker, S.N. Volkan K, Sechrist KR, Pender NJ.1988, Health Promoting Life Styles of Older Adults: Comparisons with Young and Middle-Aged Adults, Correlates and Patterns, Advances in Nursing Science, 11(1), 76-90.

[15] Esin, M. N., 1999, Sağlıklı Yaşam Biçimi Davranışları Ölçeğinin Türkçe'ye Uyarlanması, Hemşirelik Bülteni, 12 (45),87-95.

[16] Esin, N., 1997, Endüstriyel Alanda Çalışan İşçilerin Sağlık Davranışlarının Saptanması ve Geliştirilmesi, Doktora Tezi, İstanbul Üniversitesi, Sağlık Bilimleri Enstitüsü, İstanbul.

[17] Bozkuș T, Türkmen M, Kul M, Özkan A, Öz Ü, Cengiz C. 2013. Determination and Relationships of Physical Activity Level And Healthy Lifestyle Behaviors In Physical Education Students, International Journal of Science Culture and Sport, $1(3), 49-65$.

[18] Sivrikaya, A. H. Sivrikaya S.K. Altun Ö.Ş. 2013, Examination of healthy lifestyle attitudes of physical education and sports teaching department students. Balikesir Health Science Journal. 2(3): 133-138

[19] Ünalan, D. Şenol V. Öztürk A. Erkorkmaz Ü. 2007, A Research on The Relation between the Healthy Life Style Behaviors and Self-Care Levels of the Students in Health and Social Programs of Vocational Collages. İ.Ü. Tıp Fakültesi Dergisi, 14(2), 101-109.

[20] Can, G. Ozdilli K, Erol O, Unsar S, Tulek Z, Savaser S, Ozcan S, Durna Z.2008, Comparison of The Health- Promoting Lifestyles of Nursing and Non-Nursing Students in İstanbul, Turkey, Nursing \& Health Sciences, 10(4), 273-280.

[21] Altun, İ., 2008, Effect of A Health Promotion Course on Health Promoting Behaviours of University Students, Eastern Mediterranean Health Journal, 14(4), 880-887.

[22] Al-Qahtani, M.F., 2015, Health-Promoting Lifestyle Behaviors among Nurses in Private Hospitals in Al-Khobar, Saudi Arabia, Journal of the Egyptian Public Health Association,90(1), 29-34.

[23] Kafkas, M. E. Kafkas A.Ş, Acet M. 2012, Analysıs Of Physical Education Teachers' Level Of Healthy Life Style Behaviours, Dumlupinar University Journal of Social Science, 2,47-55.

[24] Nacar, M. Baykan Z, Cetinkaya F, Arslantas D, Ozer A, Coskun O, Bati H, Karaoglu N, Elmali F, Yilmaze G. 2014, Health Promoting Lifestyle Behaviour in Medical Students: a Multicentre Study from Turkey, Asian Pacific Journal of Cancer Prevention, 15, s20,s8969-s8974.

[25] Díez USM. Fortis P, 2009, A. Socio-demographic predictors of health behaviors in Mexican college students, Health Promotion International Oxford Journal, 25(1), 85-93.

[26] Stark, M. A. Manning-Walsh J, Vliem S. 2005, Caring for Self While Learning to Care for Others: A Challenge for Nursing Students, The Journal of Nursing Education, 44(6), 266-270.

[27] Fırıncı, T., 2012, Ergenlik Çağındaki Gençlerde Sağlıklı Yaşam Biçimi Araştırması, Hacettepe Üniversitesi Sosyolojik Araştırmalar E-Dergisi, 1-14.
[28] Cheung, PCH., Ip PL, Lam ST, Bibby H., 2007, A Study on Body Weight Perception and Weight Control Behaviors Among Adolescents in Hong Kong Hong Kong Medicine Journal, 13(1), s16-s21.

[29] Udo, T. Grilo CM, McKee SA. 2014, Gender Differences in The İmpact of Stressful Life Events on Changes in Body Mass İndex, Preventive Medicine, 69, 49-53.

[30] Walker, S. N. Sechrist KR, Pender NJ. 1987, The Health Promoting Lifestyle Profile Development and Psychometric Characteristics, Nursing Research, 36(2), 76-80.

[31] Yildirım, N., 2005, The effect of the health-life style behaviors of some socio-demographic characteristics of the university students, Master Thesis. Sivas Cumhuriyet University, Institute of Health Sciences.

[32] Cihangiroğlu, Z. Deveci, S.E., 2011, Healthy Life Style Behaviours and Related Influencing Factors of the Students of Elazig High School of Health Sciences of Firat University, Firat Tip Dergisi, 16, s02, 78-83.

[33] Kocaakman, M. Aksoy G. Güler HH. 2010, Healthy life style behavior of the students at the nursing college in Istanbul, Süleyman Demirel Üniversitesi Tıp Fakültesi Dergisi, 17(2), 19-24.

[34] Karadamar, M. Yiğit R. Sungur MA. 2014, Evaluation of Healthy Lifestyle Behaviours in Adolescents, Journal of Anatolia Nursing and Health Sciences, 17(3), 131-139.

[35] Lee, R.L.T. and Alice J.T.L., 2005, Health - Promoting Behaviors and Psychosocial Well-being of University Students in Hong Kong, Public Health Nursing, 22(3), 209-220.

[36] Sanchez, A. Norman GJ, Sallis JF, Calfas KJ, Cella J, Patrick K. 2007, Patterns and Correlates of Physical Activity and Nutrition Behaviors in Adolescents, American Journal of Preventive Medicine, 32(2), 124-130.

[37] Tiryaki, K., 2013, The examination of healthy lifestyle behaviors on academic staff of university Master Thesis, Gaziantep University, Graduate School of Health Sciences.

[38] Johnson, R. L., 2005, Gender Differences in Health-Promoting Lifestyles of African Americans, Public Health Nursing, 22(2), 130-137.

[39] Özyazıcıoğlu, N. Kılıç M. Erdem N. Yavuz C. Afacan S. 2011, Determinants of nursing students' healthy life style, İnternational Journal of Human Sciences, 8(2), 277-332.

[40] Wei, C. N. Harada K, Ueda K, Fukumoto K, Minamoto K, Ueda A. 2012, Assessment of Health-Promoting Lifestyle Profile in Japanese University Students, Environmental Health and Preventive Medicine,17(3), 222-227.

[41] Berçin, T., 2010, Description of health promoting lifestyle behaviors of high school students and factors affecting those behaviors. Master Thesis, Hacettepe University, Ankara.

[42] Sayg111, G. Atay E. Eraslan M. Hekim M. 2015, Investıgation Of The Relationship Between Personality Features And Academic Achievement Of Students Doing And Don't Sport Regularly. Kastamonu Eğitim Dergisi, 23(1), 161-170.

[43] Yalçınkaya, M. Özer FG. Karamanoğlu AY. 2007, Evaluation of Healthy Lifestyle Behaviors in Health Care Workers, TAF Preventive Medicine Bulletin 6(6), 409-420. 